\title{
Effect of Weed Management Strategies on Soil Nutrient Status of Apple (Malus X Domestica) under High Density Orchard System
}

\author{
Shaila Din ${ }^{1 *}$, Rayees Ah. Wani ${ }^{1}$, A. H. Pandith ${ }^{1}$, F. A. Khan ${ }^{2}$, S. A. Mir ${ }^{3}$, \\ Sameera Qayoom ${ }^{4}$, Insha Majid ${ }^{1}$, Shemoo Nisar ${ }^{1}$, Fouzia Nissar ${ }^{5}$ and Tajamul Wani ${ }^{1}$
}

${ }^{1}$ Division of Fruit Science, ${ }^{2}$ Division of Basic Science \& Humanities, ${ }^{3}$ Division of AgriStatistics, ${ }^{4}$ Division of Agronomy, ${ }^{5}$ Division of Vegetable Science, SKUAST-K, Srinagar 190025, Jammu and Kashmir

*Corresponding author

\section{A B S T R A C T}

\section{Keywords}

Elstar, Organic mulch, Inorganic mulch, Herbicides and nutrients

Article Info

Accepted: 04 September 2020 Available Online: 10 October 2020

Weed management in high density orchards is a critical component for successful crop production. The present investigation was conducted in the Experimental fields of Division of Fruit Science, SKUAST, Kashmir during the year 2018 with the aim of standardizing the effect of various weed management strategies on soil moisture and nutrient availability. One year old trees of exotic apple cv. "Elstar" grafted on M-9 T337 rootstock, introduced by SKUAST-Kashmir from Holland in March 2017, were selected for experimentation. The thirteen treatments used were replicated thrice in Factorial Randomized Complete Block Design. Different weed management practices significantly influenced the soil temperature at $0-15 \mathrm{~cm}$ depth, highest being recorded under inorganic polyethylene mulches and lowest among organic mulches. Maximum mean soil temperature of $25.63^{\circ} \mathrm{C}$ was recorded under $\mathrm{T}_{3}$ (Unpunched black polyethylene mulch) which was statistically at par with $\mathrm{T}_{2}$ (Punched black polyethylene mulch) $\left(25.59^{\circ} \mathrm{C}\right.$ ) and $\mathrm{T}_{4}$ (Bi-colour polyethylene mulch) $\left(25.38^{\circ} \mathrm{C}\right.$ ). Minimum soil temperature $\left(18.48^{0} \mathrm{C}\right)$ was recorded under paddy straw mulch $\left(\mathrm{T}_{5}\right)$. Also the available nitrogen content of the soil was markedly influenced by various weed management practices during the year of study. Maximum available nitrogen content $\left(323.78 \mathrm{Kg} \mathrm{ha}^{-1}\right)$ was recorded under paddy straw mulch $\left(\mathrm{T}_{5}\right)$ which was followed by $\mathrm{T}_{12}$ (Oxyfluorfen followed by Glufosinate ammonium) (319.89 Kg ha ${ }^{-1}$ ) and $\mathrm{T}_{11}$ (Oxyfluorfen followed by Glyphosate) (316.83 Kg ha ${ }^{-1}$ ). Minimum available nitrogen content $\left(282.11 \mathrm{Kg} \mathrm{ha}^{-1}\right)$ was recorded under unweeded control. Available phosphorus content in soil was highest $\left(22.22 \mathrm{Kg} \mathrm{ha}^{-1}\right)$ under paddy straw mulch $\left(\mathrm{T}_{5}\right)$ whereas minimum phosphorus content $\left(19.12 \mathrm{Kg} \mathrm{ha}^{-1}\right)$ was recorded under unweeded control. Available potassium content was maximum $\left(232.22 \mathrm{Kg} \mathrm{ha}^{-1}\right)$ in paddy straw mulch $\left(\mathrm{T}_{5}\right)$. Minimum potassium status $\left(201.44 \mathrm{Kg} \mathrm{ha}^{-1}\right)$ in soil was recorded under unweeded control.

\section{Introduction}

Apple (Malus $\times$ domestica Borkh), known as the king of temperate fruits, is fourth among the most widely produced fruits in the world after banana, orange and grapes. Jammu and Kashmir with the area of $1,64,742$ hectares and production of $18,82,319$ MT (2018-19) is 
leading in both area and production in the country. The productivity of apple in India is very low as compared to developed countries like China, Italy, Spain, USA etc (FAOSTAT, 2018). The high-density planting system (HDP) is now being conceived as an alternative production system having a potential for improving productivity, increasing yield efficiency, reducing input cost, minimizing risks and maximizing returns. Weed management in high density orchards is a critical component for successful crop production. The primary goal of weed management is to optimize yield by minimizing the weed competition (Merwin, 2003). Because of shallow root system in HDPs the weeds cause heavy losses by competing with the main crop for water, nutrients and also provide potential breeding niche for various insects/pests and diseases. One of the disquieting challenges in fruit production is weed management and can be managed through various management strategies like manual, mechanical, cultural, biological and chemical control (Hira et al., 2004). Nevertheless, manual weed control is not only laborious but is also highly expensive. In addition to this, annual and mechanical weeding can cause damage to the shallow root system in high density plantations. Thus, of late, manual and mechanical weed control methods are gradually being replaced by other alternatives such as the use of mulches and herbicides as these are easier, cheaper and less time consuming. These management strategies, except use of herbicides, not only suppress the growth and development of weeds but also improve soil conditions, structure and soil nutrient status and impart manifold beneficial effects, like, stabilization of soil temperature, reduced water loss through evaporation, increased water holding capacity of soil, and improvement in growth and yield (Shirgure et al., 2003).The use of mulches for weed control is a well-established practice to improve plant performance. Mulching plays an important role in the conservation of soil moisture (Hira et al., 2004) during dry periods besides offering the advantage like suppression of weed growth (Kaur and Kaundal, 2009), reducing water runoff and soil erosion, provide cover for rodents that damage tree roots and trunks, improve water and fertilizer use efficiency (Salaria, 2009). Various materials of plant origin like straw, saw dust, wood chips, shredded paper (Rowley et al, 2011), hay, crop residues and synthetic material like polyethylene plastic (Camposeo and Vivaldi, 2011), woven polypropylene fabric (Rozpara et al., 2008), non-woven polyacrylic fabric (Camposeo and Vivaldi, 2011) have been extensively used as soil mulch in fruit orchards. Also new fabrics are being developed with white colour on top (to reflect light and heat) and black on bottom to suppress weeds (Makus, 2007). However, complete elimination of weed competition in orchards is possible with residual herbicides (Merwin, 2003). Herbicides are the most important weed control tools for alleviating the infestation of weeds and getting higher yield as reported by Ashiq et al., (2007). Herbicidal weed control seems indispensable and has proved efficient in controlling weeds (Kahramanoglu and Uygur, 2010) and hence presently about two-third, by volume, of the pesticides used worldwide in agricultural production are herbicides. Herbicides are observed to be highly effective and economical in fruit orchard besides giving the satisfactory level of weed control when applied as pre-emergent or post-emergent. It also offers several advantages such as longevity of treatment, stimulation of plant growth, effective weed control, easily executed, are relatively cheap, and ensure high yielding of trees (Harrington et al., 2005). Keeping in view the above facts, the present study was carried out in high density apple blocks with the objective of standardizing the effect of various weed 
management strategies on soil temperature and soil nutrient availability.

\section{Materials and Methods}

\section{Experimental site and climatic conditions}

The present investigation entitled "Effect of Weed Management Strategies on Soil Nutrient Status of Apple Under High Density Orchard System" was carried out in the experimental fields of Division of Fruit Science, Sher-e-Kashmir University of Agricultural Science \& Technology of Kashmir, Shalimar, Srinagar, Jammu \& Kashmir during the year 2018. The experimental site is located at $34.1^{\circ}$ North latitude and $74.9^{\circ}$ East longitude. During the experimentation period, the average maximum temperature recorded was $25.3^{\circ} \mathrm{C}$ and the average minimum temperature recorded was $10.9^{\circ} \mathrm{C}$. The total precipitation of $800.8 \mathrm{~mm}$ was received during 2018 .

\section{Soil}

Before the start of the experiment, composite sample of the soil from $0-15 \mathrm{~cm}$ depth from all the replications was collected. The procedure followed for the analysis of soil for various chemical characteristics and the results obtained are given in Table 1.

\section{Planting material}

One year old trees of exotic apple cv. "Elstar, spaced 1 × $3 \mathrm{~m}$ (3333 trees /ha), grafted on M-9 T337 rootstock and introduced by SKUASTKashmir from Holland in March 2017 were selected for experimentation. The trees of uniform size, vigour and bearing capacity were selected for experiment. All the trees under study received uniform cultural practices during the year as per the package of practices of SKUAST-Kashmir. Treatments and replications were randomly assigned with a single plot size.

\section{Experimental details}

Thirteen treatments comprising of various organic and inorganic mulches and also pre and post emergent herbicides were laid out in Randomized complete block design (RCBD), with each treatment replicated thrice. The mulches were applied during the last the last week of March. The commercial formulations of pre and post- emergent herbicides were sprayed with high volume Knapsack sprayer. Pre-emergent herbicide was applied during the first week of March, whereas postemergent herbicides were applied during midJune. The details of the pre and post emergent herbicides used are given in Table 2 .

\section{Active ingredient (a.i.)}

It is a part of chemical formulation which is directly responsible for herbicidal effect. Thus, the commercial herbicide is made up of two parts i.e. the effective part and the inert part. Since all the recommendations are made on the basis of a.i., herbicides quantity was calculated with following formula:

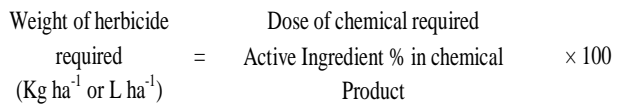

\section{Soil temperature $\left({ }^{\circ} \mathrm{C}\right)$}

Soil temperature $\left({ }^{\circ} \mathrm{C}\right)$ of each experimental treatment was recorded at depth of $0-15 \mathrm{~cm}$ with the help of soil thermometer. First reading was taken on $1^{\text {st }}$ May and subsequent readings at 30 days intervals. Final reading was recorded at the time of harvesting.

\section{Soil pH}

Soil $\mathrm{pH}$ was determined in 1:2.5 soil: water suspension using $\mathrm{pH}$ meter with glass electrode as described by Jackson (1973). 
Available nitrogen $\left(\mathrm{Kg} \mathrm{ha}^{-1}\right)$

Available nitrogen was determined by alkaline potassium permanganate distillation method as described by Subbiah and Asija (1956).

\section{Available phosphorus (Kg ha $\left.{ }^{-1}\right)$}

Available phosphorus content of the soil was determined by Olsen method using $0.5 \mathrm{~N}$ sodium bicarbonate at $\mathrm{pH} 8.5$ (Olsen et al., 1954).

\section{Available potassium $\left(\mathrm{Kg} \mathrm{ha}^{-1}\right)$}

Available potassium was extracted with neutral $1 \mathrm{~N}$ ammonium acetate at 1:5 soil to extract ratio and the content of potassium was estimated by Flame photometer (Jackson, 1973).

\section{Statistical analysis}

The data recorded under study was subjected to standard statistical analysis as followed by Gomez and Gomez (1984) using the statistical software (SAS), according to randomized complete block design. The treatment effects were tested at 5 per cent level of significance.

\section{Results and Discussion}

The data presented in Table 3 indicate that different weed management practices significantly influenced the soil temperature at $0-15 \mathrm{~cm}$ depth, highest being recorded under inorganic polyethylene mulches and lowest among organic mulches. Maximum mean soil temperature of $25.63{ }^{\circ} \mathrm{C}$ was recorded under $\mathrm{T}_{3}$ (Unpunched black polyethylene mulch) which was statistically at par with $\mathrm{T}_{2}$ (Punched black polyethylene mulch) $\left(25.59{ }^{0} \mathrm{C}\right.$ ) and $\mathrm{T}_{4}$ (Bi-colour polyethylene mulch) $\left(25.38{ }^{0} \mathrm{C}\right)$. Further investigation of data revealed that treatments
$\mathrm{T}_{8}$ (Oxyfluorfen), $\mathrm{T}_{12}$ (Oxyfluorfen followed by Glufosinate ammonium), $\mathrm{T}_{10}$ (Glufosinate ammonium), $\mathrm{T}_{9}$ (Glyphosate) and $\mathrm{T}_{11}$ (Oxyfluorfen followed by Glyphosate) were statistically at par for their effect on soil temperature. Minimum soil temperature $\left(18.48{ }^{\circ} \mathrm{C}\right)$ was recorded under paddy straw mulch $\left(\mathrm{T}_{5}\right)$. Among different days after treatments of observation, maximum soil temperature $\left(23.37^{\circ} \mathrm{C}\right)$ was recorded on 90 days and 120 days. However minimum soil temperature was recorded on 30 days (19.75 $\left.{ }^{0} \mathrm{C}\right)$. Among treatments and days after treatments interaction, maximum soil temperature $\left(27.43^{\circ} \mathrm{C}\right)$ was recorded under unpunched black polyethylene mulch on 90 days, which was statistically at par with $\mathrm{T}_{2}$ on 90 and 120 days and also with $\mathrm{T}_{3}$ on 120 days. An increase in soil temperature, under inorganic mulches (black polythene and bicoloured polythene mulch), may be attributed to the fact that these mulches absorb more radiation from Sun and thus transmit more heat to the upper layer of soil as compared to other organic mulches. These results are in accordance with the findings of Ramakrishna et al., (2006), Sharma and Kathiravan (2009), Liu et al., (2014) and Hussain et al., (2018), who reported higher temperature under polythene mulches as compared to other organic mulches, herbicide treated soil and bare soils in various fruit crops.

The decrease in soil temperature under organic mulches may be due to the fact that organic mulches, generally, insulate the orchard soil against heat and have low thermal conductivity and thus reduce the heat flux, acting as a coolant besides retarding diurnal and internal temperature fluctuations (Greenham, 1953; Engel, 1960). Organic matter mulch treatments decreased the peak temperature of orchard soil in the summer and increased the minimum soil temperature in the fall. 
Table.1 Chemical characteristic of experimental orchard soil

\begin{tabular}{|c|c|c|}
\hline Particular & Content & Method followed \\
\hline Soil pH & 6.54 & $\begin{array}{l}\text { 1:25 soil: water suspension using pH meter with } \\
\text { glass electrode (Jackson, 1973) }\end{array}$ \\
\hline $\begin{array}{l}\text { Available Nitrogen } \\
\qquad\left(\mathrm{Kg} \mathrm{ha}^{-1}\right)\end{array}$ & 289.26 & $\begin{array}{l}\text { Alkaline potassium permanganate distillation } \\
\text { method (Subbiah and Asija, 1956) }\end{array}$ \\
\hline $\begin{array}{l}\text { Available phosphorus } \\
\qquad\left(\mathrm{Kg} \mathrm{ha}^{-1}\right)\end{array}$ & 20.54 & Olsen's method (Jackson, 1973). \\
\hline $\begin{array}{l}\text { Available potassium } \\
\left(\mathrm{Kg} \mathrm{ha}^{-1}\right)\end{array}$ & 210.86 & $\begin{array}{l}\text { Neutral normal ammonium acetate method } \\
\text { (Jackson, 1973) }\end{array}$ \\
\hline
\end{tabular}

Table.2 Details of the herbicides used in present studies

\begin{tabular}{|c|c|c|c|c|}
\hline Common Name & Trade Name & $\boldsymbol{a . i .}$ & IUPAC Name & Manufacturer \\
\hline Oxyflourfen & Galigan & $23.5 \% \mathrm{EC}$ & $\begin{array}{c}\text { 2-Chloro-1-(3-ethoxy-4- } \\
\text { nitrophenoxy)-4- } \\
\text { (trifluoromethyl)benzene }\end{array}$ & ADAMA India Private Limited \\
\hline Glyphosate & Roundup & $41 \% \mathrm{SL}$ & $\begin{array}{c}2- \\
\text { (phosphonomethylamino) } \\
\text { acetic acid }\end{array}$ & Monsanto India limited \\
\hline $\begin{array}{c}\text { Glufosinate } \\
\text { Ammonium }\end{array}$ & Mera71 & $71 \% \mathrm{SG}$ & $\begin{array}{c}\text { 2-amino-4- } \\
\text { [hydroxyl(methyl)phosph } \\
\text { o-ryl] butanoic acid }\end{array}$ & Excel Crop Care Limited \\
\hline
\end{tabular}

Table.3 Effect of weed management strategies on soil temperature of apple cv. Elstar under high density orchard system

\begin{tabular}{|c|c|c|c|c|c|}
\hline \multirow{2}{*}{$\begin{array}{l}\text { Days after reference date }\left(1^{\text {st }} \text { April }\right) \\
\text { Treatments }\end{array}$} & \multicolumn{5}{|c|}{ Soil temperature $\left({ }^{\circ} \mathrm{C}\right)$} \\
\hline & 30 & 60 & 90 & 120 & Mean \\
\hline $\begin{array}{l}T_{1}: \text { Farmer's Practice (Hoeing at } 45 \text { days interval, } 3 \text { hoeing's starting from } \\
\text { last week of March) }\end{array}$ & 20.07 & 21.80 & 22.93 & 22.57 & 21.84 \\
\hline 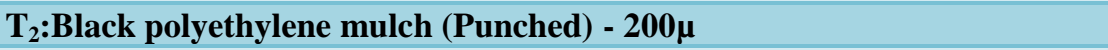 & 21.83 & 26.33 & 27.30 & 26.90 & 25.59 \\
\hline$T_{3}$ :Black polyethylene mulch (Unpunched) - $200 \mu$ & 21.87 & 26.33 & 27.43 & 26.90 & 25.63 \\
\hline $\mathrm{T}_{4}:$ Bi-Colour polyethylene mulch - $200 \mu$ & 22.67 & 25.70 & 26.87 & 26.30 & 25.38 \\
\hline $\mathrm{T}_{5}:$ Paddy Straw mulch $-10 \mathrm{~cm}$ thickness & 16.07 & 18.70 & 19.40 & 19.77 & 18.48 \\
\hline$T_{6}:$ Forest Litter (Pine Needles) - 10cm thickness & 16.73 & 18.40 & 18.90 & 19.97 & 18.50 \\
\hline$T_{7}:$ Chopped lawn grass - $5 \mathrm{~cm}$ thickness & 17.50 & 18.70 & 19.03 & 18.97 & $\mathbf{1 8 . 5 5}$ \\
\hline $\mathrm{T}_{8}$ :Oxyfluorfen @ 0.5 L ha ${ }^{-1}$ Pre-emergence herbicide) & 19.60 & 22.93 & 24.77 & 23.97 & 22.82 \\
\hline $\mathrm{T}_{9}:$ Glyphosate @ 2.0 L ha ${ }^{-1}$ (Post-emergence) & 20.07 & 21.93 & 23.67 & 24.30 & 22.49 \\
\hline $\mathrm{T}_{10}:$ Glufosinate ammonium @ $0.84 \mathrm{Kg} \mathrm{ha}^{-1}$ (Post-emergence) & 19.67 & 22.60 & 24.33 & 23.77 & 22.59 \\
\hline $\begin{array}{l}\mathrm{T}_{11} \text { :Oxyfluorfen @ } 0.5 \mathrm{~L} \mathrm{ha}^{-1} \text { (Pre-emergence herbicide) followed by } \\
\text { Glyphosate @ } 2.0 \mathrm{~L} \mathrm{ha}^{-1} \text { (Post-emergence) }\end{array}$ & 19.73 & 21.87 & 23.43 & 23.83 & 22.22 \\
\hline $\begin{array}{l}\mathrm{T}_{12} \text { :Oxyfluorfen @ } 0.5 \mathrm{~L} \mathrm{ha}^{-1} \text { (Pre-emergence herbicide) followed by } \\
\text { Glufosinate ammonium @ } 0.84 \mathrm{Kg} \mathrm{ha}^{-1} \text { (Post-emergence) }\end{array}$ & 20.20 & 22.87 & 23.70 & 23.77 & 22.63 \\
\hline$T_{13}$ :No Weeding (Control) & 20.73 & 21.17 & 22.00 & 22.40 & 21.58 \\
\hline Mean & 19.75 & 22.26 & 23.37 & 23.37 & \\
\hline
\end{tabular}

C.D $(\leq 0.05)$

$\begin{array}{llll}\text { Treatments } & : & 0.623 & \\ \text { Days } & & : & 0.346 \\ \text { Treatment x Days } & : & 1.246 & \end{array}$


Table.4 Effect of weed management strategies on soil characteristics of apple cv. Elstar under high density orchard system

\begin{tabular}{|c|c|c|c|c|}
\hline Treatments & pH & $\begin{array}{l}\text { Nitrogen } \\
\left(\mathrm{Kg} \mathrm{ha}^{-1}\right)\end{array}$ & $\begin{array}{l}\text { Phosphorus } \\
\left(\mathrm{Kg} \mathrm{ha}^{-1}\right)\end{array}$ & $\begin{array}{l}\text { Potassium } \\
\left(\mathrm{Kg} \mathrm{ha}^{-1}\right)\end{array}$ \\
\hline $\begin{array}{l}T_{1}: \text { Farmer's Practice (Hoeing at } 45 \text { days interval, } 3 \text { hoeing's } \\
\text { starting from last week of March) }\end{array}$ & 6.48 & 291.76 & 19.56 & 209.37 \\
\hline$T_{2}$ :Black polyethylene mulch (Punched) - $200 \mu$ & 6.50 & 305.97 & 21.68 & 223.93 \\
\hline$T_{3}$ :Black polyethylene mulch (Unpunched) - $200 \mu$ & 6.53 & 305.38 & 21.55 & 223.04 \\
\hline$T_{4}: B i-C o l o u r$ polyethylene mulch - $200 \mu$ & 6.54 & 306.22 & 21.96 & 224.29 \\
\hline$T_{5}:$ Paddy Straw mulch $-10 \mathrm{~cm}$ thickness & 6.54 & 323.78 & 22.22 & 232.22 \\
\hline$T_{6}:$ Forest Litter (Pine Needles) - $10 \mathrm{~cm}$ thickness & 6.47 & 314.57 & 21.92 & 231.28 \\
\hline $\mathrm{T}_{7}:$ Chopped lawn grass $-5 \mathrm{~cm}$ thickness & 6.55 & 315.56 & 21.67 & 230.32 \\
\hline $\mathrm{T}_{8}:$ Oxyfluorfen @0.5 L ha ${ }^{-1}$ (Pre-emergence herbicide) & 6.62 & 297.21 & 20.60 & 211.34 \\
\hline T9:Glyphosate@ $@$.0 L ha ${ }^{-1}$ (Post-emergence) & 6.57 & 293.78 & 20.68 & 212.33 \\
\hline $\mathrm{T}_{10}$ :Glufosinate ammonium @ $0.84 \mathrm{Kg} \mathrm{ha}^{-1}$ (Post-emergence) & 6.56 & 294.85 & 21.04 & 212.27 \\
\hline $\begin{array}{l}T_{11}: \text { Oxyfluorfen @ } 0.5 \mathrm{~L} \mathrm{ha}^{-1} \text { (Pre-emergence herbicide) } \\
\text { followed by Glyphosate @ 2.0 L ha }{ }^{-1} \text { (Post-emergence) }\end{array}$ & 6.57 & 316.83 & 21.44 & 226.51 \\
\hline $\begin{array}{l}T_{12}: \text { Oxyfluorfen @ } 0.5 \mathrm{~L} \mathrm{ha}^{-1} \text { (Pre-emergence herbicide) } \\
\text { followed by Glufosinate ammonium @ } 0.84 \mathrm{Kg} \mathrm{ha}^{-1} \text { (Post- } \\
\text { emergence) }\end{array}$ & 6.57 & 319.89 & 21.81 & 227.91 \\
\hline$T_{13}:$ No Weeding (Control) & 6.46 & 282.11 & 19.12 & 201.44 \\
\hline C.D. $(p \leq 0.05)$ & NS & 2.432 & 0.953 & 1.583 \\
\hline
\end{tabular}

Fig.1 View of experimental field, Division of Fruit Science, SKUAST- Kashmir
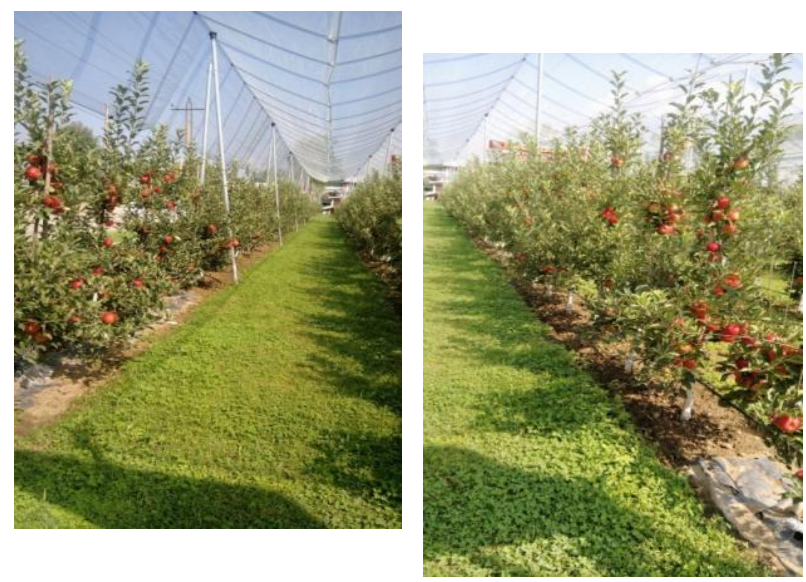

As evident from the data presented in Table 4 different weed management practices had a non-significant effect on soil $\mathrm{pH}$. The data presented in Table 4 reveals that the available nitrogen content of the soil was markedly influenced by various weed management practices during the year of study. Maximum available nitrogen content $\left(323.78 \mathrm{Kg} \mathrm{ha}^{-1}\right)$ was recorded under paddy straw mulch $\left(\mathrm{T}_{5}\right)$ which was followed by $\mathrm{T}_{12}$ (Oxyfluorfen 
followed by Glufosinate ammonium) (319.89 $\mathrm{Kg} \mathrm{ha}^{-1}$ ) and $\mathrm{T}_{11}$ (Oxyfluorfen followed by Glyphosate) (316.83 Kg ha ${ }^{-1}$ ). The minimum available nitrogen content $\left(282.11 \mathrm{Kg} \mathrm{ha}^{-1}\right)$ was recorded under unweeded control. Similar observations where observed for phosphorus and potassium uptake. It is apparent from the data (Table 4) that available phosphorus content in soil was highest (22.22 $\mathrm{Kg} \mathrm{ha}^{-1}$ ) under paddy straw mulch $\left(\mathrm{T}_{5}\right)$. This maximum value was statistically at par with treatments $\mathrm{T}_{4}$ (Bi-colour polyethylene mulch) $\left(21.96 \mathrm{Kg} \mathrm{ha}^{-1}\right), \mathrm{T}_{6}$ (Forest litter) $(21.92 \mathrm{Kg}$ $\mathrm{ha}^{-1}$ ), $\quad \mathrm{T}_{12} \quad$ (Oxyfluorfen followed by Glufosinate ammonium) (21.81 Kg ha $\left.{ }^{-1}\right), \mathrm{T}_{2}$ (Punched black polyethylene mulch) (21.68 $\left.\mathrm{Kg} \mathrm{ha}^{-1}\right), \mathrm{T}_{7}$ (Chopped lawn grass) $(21.67 \mathrm{Kg}$ $\mathrm{ha}^{-1}$ ), $\mathrm{T}_{3}$ (Unpunched black polyethylene mulch) (21.55 Kg ha ${ }^{-1}$ ) and $\mathrm{T}_{11}$ (Oxyfluorfen followed by Glyphosate) (21.44 $\left.\mathrm{Kg} \mathrm{ha}^{-1}\right)$. However, minimum phosphorus content $\left(19.12 \mathrm{Kg} \mathrm{ha}^{-1}\right)$ was recorded under unweeded control. As evident from the data (Table 4) available potassium content was maximum (232.22 $\left.\mathrm{Kg} \mathrm{ha}^{-1}\right)$ in paddy straw mulch $\left(\mathrm{T}_{5}\right)$ which was statistically at par with $\mathrm{T}_{6}$ (Forest litter) $\left(231.28 \mathrm{Kg} \mathrm{ha}^{-1}\right)$. Minimum potassium status $\left(201.44 \mathrm{Kg} \mathrm{ha}^{-1}\right)$ in soil was recorded under unweeded control $\left(\mathrm{T}_{13}\right)$. As evident from the data available potassium content was maximum.

In the present studies, various weed management treatments, increased the availability of all the macronutrients compared to unweeded control. The increase in available nutrients in soil solution may be due to reduced competition through effective weed control and increased organic carbon contents of the soil, leading to increased nutrient availability in soil solution and, also the humus, a resultant of organic carbon, decomposition, caused more release of cations from exchange complex of the soil. These findings are in accordance with Rao and Pathak (1998) who worked on aonla cv.
Francis under Faizabad conditions of Utter Pradesh. Shylla et al., (1998) who worked on plum cv. Santa Rosa under Solan conditions of Himachal Pradesh also reported that the use of herbicide resulted in higher available nitrogen content in soil than mulch and minimum available nitrogen content was registered in clean cultivation treatment. The present findings are also in accordance with the work of Atucha et al., (2011), who worked on apple under New York conditions of USA and reported that maximum available nitrogen in soil was observed under preemergence herbicides treatment followed by post-emergence herbicides and minimum value of was in sod culture treatment. Application of glyphosate based herbicide increased the soil available phosphate by $127 \%$ compared to non treated plots (Berghausen et al., 2015). Trimurtulu et al., (2015) also reported increase of available phosphorus to the maximum of $31.0 \mathrm{Kg}$ $\mathrm{P}_{2} \mathrm{O}_{5} /$ ha by the used of herbicide oxyfluorfen. The results are in contradiction to the findings of Rao and Pathak (1998) in aonla cv. Francis and reported that highest available phosphorus content was observed in soil under control followed by rice husk and minimum in paddy straw mulch. Rao and Pathak (1998) and Meena et al., (2015) who reported highest available potassium content in soil under paddy straw mulch in aonla. The higher available potassium content in tree basin was directly associated with rapid decomposition of organic mulches. Similar increase in available potassium in soil by use of herbicides for weed control was reported by Bhat (2004) and Sharma (2004) in plum, apricot and strawberry respectively.

From the present investigation it can be concluded that organic mulches act as insulators and helps in maintaining lower soil temperature besides conserving moisture. Also the adoption of various weed management practices, particularly use of 
organic mulch and herbicides markedly increased the soil micronutrient content. Highest macronutrient content (N, P and K) was observed under paddy straw mulch but use of paddy straw mulch increase the chance of rodent infestation. Thus for reduction of nutrient loss through weed and ensuring nutrient utilization by main crop, application of pre-emergent herbicide (Oxyfluorfen @ 0.5 $\mathrm{L} \mathrm{ha}^{-1}$ ) followed by the application of postemergent herbicide (Glufosinate ammonium @ $0.84 \mathrm{Kg} \mathrm{ha}^{-1}$ ) can be used for effective controll of weeds in apple under high density orchard system in Kashmir conditions.

\section{References}

Ashiq, M., Sattar, A., Ahmed, N. and Muhammad, N. 2007. Role of herbicides in crop production. Unique enterprises 17-A, Gulberg colony, Faisalabad, Pakistan

Atucha, A., Ian, A. M. and Brown, M. G. 2011. Long-term effects of four groundcover management systems in an apple orchard. HortScience 46(8): 11761183.

Berghausen, M. G., Hofer, M., Rewald, B. and Zaller, J.G. 2015. Glyphosate based herbicides reduce the activity and reproduction of earthworms and lead to increased soil nutrient concentrations. Scientific Report 5:12886

Bhat, D. J. 2004. Effect of herbicide, N, K and orchard floor management practices on growth, yield and fruit quality of apricot (Prunus armeniaca L.). Ph.D. Thesis, Dr. Y.S. Parmar University of Horticulture and Forestry, Nauni, Solan (H.P.).

Camposeo S., Vivaldi G. A. 2011. Short-term effects of of de-oiled pomace mulching on a young super high density olive orchard. Scientia Horticulturae 129 (4): 613-621.

FAOSTAT, 2015-16. Food and Agricultural
Organization. Statistical Database on World Fruit Production. www. fao. org. Gomez, K. A. and Gomez, A. A. 1984. Statistical Procedures for Agricultural Research ( $2^{\text {nd }}$ edition). Hohn Willey and Sons, New York, USA pp. 28-92.

Greenham, D. W. P. 1953. Orchard soil management. 13th International Horticultural Congress, London 1: 181189.

Hira, G. S., Jalota, S. K. and Arora, V. K. 2004. Efficient management of water resources for sustainable cropping in Punjab. Technical Bulletin. Department of Soils, Punjab Agricultural University, India, $20 \mathrm{pp}$.

Hussain, S., Sharma, M. K., Bashir, D., Tundup, P., Bangroo, S.A. and Kumar, A. 2018. Effect of Orchard Floor Management Practices on Nutrient Status in Apple cv. Royal Delicious. International Journal of current microbiology and applied science 7(2): 2771-2792

Jackson, M. L. 1973. Soil Chemical Analysis. Prentice Hall of India Private Limited, New Delhi pp. 38-82.

Kahramanoglu and Uygur, F. N. 2010. The effects of reduced doses and application timing of metribuzin on redroot pigweed (Amaranthus retroflexus L.) and wild mustard (Sinapis arvensis L.). Turkish Journal of Agriculture and Forestry 34: 467-474.

Liu, Y., Wang, J., Liu, D., Li, Z., Zhang, G., Tao, Y., Xie, J., Pan, J. and Chen, F. 2014. Straw mulching reduces the harmful effects of extreme hydrological and temperature conditions in citrus orchards. PLOS One 9(1): e87094.

Makus, D. 2007. Use of fabric and plastic barriers to control weeds in blackberries. Journal of Subtropical Plant Science 59: 95-103.

Meena, M. K., Sharma, D. D. and Meena, O. P. 2015. Effect of different weed 
management practices on weed population, yield potential and nutrient status of peach cv. July Elberta. Research on Crops 16 (3): 519-525.

Merwin I. A. 2003. Orchard-floor management systems. In: Ferree D. C, Warrington I. J. Apples: botany, production and uses. CABI Publishing, Cambridge pp 303-318.

Olsen, S. R., Cole, C. V., Wantanabe, F. S. and Dean, L. A. 1954. Estimation of available phosphorous in soils by extraction with sodium bicarbonate. USDA Circular, 939.

Ramakrishna, A., Tam, H. M., Wani, S. P. and Long, T. D. 2006. Effect of mulch on soil temperature, moisture, weed infestation and yield of groundnut in northern Vietnam. Field Crops Research 95: 115-125.

Rao, V. K. and Pathak, R. K. 1998. Effect of mulches on aonla (Emblica officinalis Gaertn) orchard in sodic soil. Indian Journal of Horticulture 55: 27-37.

Rowley M. A., Ransom C. V., Reeve J. R., Black B. L. 2011. Mulch and organic herbicide combinations for in-row orchard weed suppression. International Journal of Fruit Science 11(4): 316331.

Salaria, A. 2009. Horticulture at a glance. Handbook for Competitive Exams. Volume 2. Jain Brothers, East Park Road, Karol Bagh, New Delhi pp. 234235.

Sharma, C. L. 2004. Response of N, K and orchard floor management systems on growth, yield and quality of strawberry (Fragaria $\mathrm{x}$ ananassa Duch.) cv. Chandler. Ph.D. Thesis, Dr. Y.S. Parmar University of Horticulture and Forestry, Nauni, Solan (H.P.).

Sharma, J. C. and Kathiravan, G. 2009. Effect of mulches on soil hydrothermal regimes and growth of plum in mid hill region of Himachal Pradesh. Indian Journal of Horticulture 66(4): 465-471.

Shirgure, P. S., Sonkar, R. K., Singh, S. and Panigrahi, P. 2003 Effect of different mulches on soil moisture conservation, weed reduction, growth and yield of drip irrigated Nagpur mandarin (Citrus reticulate). Indian Journal of Agricultural Sciences 73(3): 148-52.

Shylla, B., Chauhan, J. S., Awasthi, R. P. and Bhandari, A. R. 1998. Effect of orchard floor-management practices on soil physico-chemical properties of plum. Indian Journal of Horticulture 55(2): 153-156.

Subbiah, B. V. and Asija, J. S. 1956. A rapid procedure for the estimation of available nitrogen in the soil. Current Science 25: 259-260.

Trimurtulu, N., Ashok, S., Latha, M. and Rao, A. S. 2015. Influence of pre-emergence herbicides on the soil microflora during the crop growth of blackgram, Vigna mungo. L. International journal of current microbiology and applied science 4(6): 539-546.

\section{How to cite this article:}

Shaila Din, Rayees Ah. Wani, A. H. Pandith, F. A. Khan, S. A. Mir, Sameera Qayoom, Insha Majid, Shemoo Nisar, Fouzia Nissar and Tajamul Wani. 2020. Effect of Weed Management Strategies on Soil Nutrient Status of Apple (Malus X Domestica) under High Density Orchard System. Int.J.Curr.Microbiol.App.Sci. 9(10): 323-331. doi: https://doi.org/10.20546/ijcmas.2020.910.040 